\title{
Common Law and Jewish Law. The Diasporic Principle of dina de-malkhuta dina
}

\author{
Sylvie Anne Goldberg
}

\begin{abstract}
Medieval rabbis conceived of a legal framework for the relations between Jews and non-Jews according to a principle: dina de-malkhuta dina, 'the Law of the Kingdom is Law.' This framework depended on the fact that Jews were living in Galut, Diaspora. Thus, the notion of Diaspora, which in the last century came to be used to refer to the fate of migrants in general, bears a dual legal connotation in Judaism. This article tries first, by tracing back the origin of the word "galut" or "golah" (translated as "exile") in Antiquity, to demonstrate how it is related to the core of Jewish definitions of the "present" as construed by Rabbinic Judaism. It then ventures across the boundaries of time and place to question the purely theological and particularly Jewish evolution of this concept. It is an attempt to apprehend the ways in which the evolution of the notion of Diaspora bears witness to the transformation of the history of the Jews.
\end{abstract}

Keywords: Jerusalem; Diaspora; Exile; Jewishness; Law; dina de-malkhuta dina

"And I spoke [...] saying: 'Bring your necks under the yoke of the king of Babylon, and serve him and his people, and live. Why will ye die, thou and thy people, by the sword, by the famine, and by the pestilence, as the LORD hath spoken concerning the nation that will not serve the king of Babylon? And hearken not unto the words of the prophets that speak unto you, saying: Ye shall not serve the king of Babylon, for they prophesy a lie unto you. For I have not sent them, saith the LORD, and they prophesy falsely in My name; that I might drive you out, and that ye might perish, ye, and the prophets that prophesy unto you.' [...] serve the king of Babylon, and live; wherefore should this city become desolate?" (Jer. 27, 12-17) ${ }^{1}$

The remembrance of the ancient kingdom of Israel, which lasted only for a short period during Antiquity, posed a completely new and unfamiliar dilemma for the Jews of the $20^{\text {th }}$ century. If, on the one hand, they had to re-strengthen ties between all the scattered communities to give shape to a national entity, on the other, they also had to question the meaning of "who is a Jew" according to the conception of the modern laws of 
states and long-established Jewish Law. ${ }^{2}$ To enact new rules in the State of Israel, the Israelis had to scrutinize their political and social history of the past two centuries to understand both the place they could claim amid nations as well as the diversity of Jewish identities in a new framework to be constructed between both membership of a religious denomination and membership of a new state. In addition, they had to ultimately make a choice between staying in "diaspora" or leaving their country of residence to join the newborn state in Palestine.

By reinstating the former sovereignty of the Jews in their ancient homeland, the State of Israel has revived what seemed to be an age-old dialectic between Jews from Israel and Jews from Diaspora, reopening the question of the relationship between a centre and its periphery. In light of the present tangled political situation, it is very tempting, since it was also at the beginning of the struggle for the political legitimacy of Zionism, to seek similarities between the past and the present, even if both situations were quite different. Furthermore, the unceasing repercussions upon Jewish life outside Israel emanating from the conflict raging in the Middle East harshly highlights the complexity of the meanings given to the notions of Jewish Diaspora or Exile, in Hebrew Galut - the situation of exile or Golah - being abroad, which are used in modern attempts to describe the history and the nature of the so-called "Jewish phenomenon" to account for the persistence of the Jewish people during history in spite of their lack of a homeland.

This article seeks to explore the relevance of similarities between ancient and modern connotations of the term "diaspora." I will examine some of the characteristics of the ancient Diaspora, in its time and place, and will discuss the meanings of some of these related terms, such as "galut" and "golah," in light of the cultural and religious evolutions as expressed in the contemporary sense given to the word "diaspora." At the same time, I will present some remarks on the supposed uniqueness of Jewishness, which can be seen as a purely theological convention springing from history.

There is much historical evidence showing that no reasonable analogy can be drawn between the present-day situation of the State of Israel and the Judean Roman Province. Nevertheless, if one holds that Judaism does have roughly the same essential components at its very core, and that the same kind of relationship prevails now between the Jews living outside of Israel and those who then chose to move - or were sent - far away from Palestine, a series of questions can be raised. First, one can ask whether the conceptions and contents of the term "diaspora" have changed or not over time? Second, one can wonder whether the longevity and extensions of the word "diaspora" are a challenge to the present reshuffling of the Jewish political world or not? Third, one can question the dialectic between Israel and the Diaspora, asking whether it has ever been really so unambiguous? Moreover, one can properly ask: were all the clichés conveyed by the bulk of theological meanings attached to the words "diaspora," "galut," and "exile" truly grounded in history, or were they rather invented piecemeal over the course of the centuries? Even if this article appears to be - and surely is - nothing more than a provocative venture to answer these questions, I hope to argue convincingly that these points are worth serious discussion.

2 See the crisis and the debate opened at the Knesset in 1958 on the question in Dromi 2005, especially 96-162. See also Ben Raphael 2002. 


\section{The Galut as Seen by Theology and the Social Sciences}

Since the term "diaspora" has become a universal lexeme based on a Greek etymon, and coined in the vernacular languages, to signify the fate of migrants wherever their actual place of residence was located, it is useful to recall its original meaning to identify its semantic transformations. According to an etymological dictionary, the term "diaspora" stems from the Septuagint translation of the Hebrew Bible. Taken from the ancient Greek, the term was intended to describe, in essence, the condition of the Jews scattered all over the world, outside the Land of Israel, as was written "and shalt be dispersed ( $d i$ aspeirein) into all the kingdoms of the earth" (Dtn 28, 25; Van Unnik 1993). Used for at least 2,000 years, and most probably even since the first exile of the Jews to Babylonia (586 BCE), the term came to illustrate the Divine decision to punish the people of Israel by banishing it from the Promised Land. Thus, for centuries, it became associated with a religious sense of exile. Even if the Hebrew word for exile, "galut," does not originally mark any difference between simple dispersion and theological exile (Milikowsky 1997, 265-295), it was constantly imbued with numerous theological interpretations. Grounded in Judaism, e.g., the threat of banishment prophesied by Jeremiah and mentioned earlier in this article, and the concept of punishment mentioned elsewhere in the Book of Ezekiel, it was further promoted by Christianity. It saw in the Jewish Diaspora its true sanction for not having recognized Jesus as the son of the Lord. Islam endorsed the same position, but added to it the refusal of the Jews to hear Muhammad's call.

From its early Greek etymological origin, the term expanded widely as it entered the realms of modern scholarship. Coined around 1880 to describe the spread of populations and groups into foreign countries, it has since come to pervade the ordinary specialized vocabulary of the social sciences and become an archetype actually deprived of any theological significance. ${ }^{3}$ The archetype of the Jewish Diaspora became the common label for all other displaced communities (Eleazar 1997, chap. 5; Shmueli 1980), though Herodotus (Godley 6,119) recalls the same phenomenon for Eretrians taken captive by Darius and Diodorus Siculus for other "barbarians" (Godley 34-35; 4,1-2). In fact, many a testimony from Antiquity indeed attests to the fact that Jews from all over the Hellenistic world preserved the ancient custom to journey to Eretz Israel on the three pilgrimage festivals, the solemn celebrations occurring in autumn and spring. Sources also relate that the largest cities in the Diaspora sent delegates to represent them, who brought offerings and attended the sacrifices in the name of all the Jewish inhabitants of the colonies. Ancient sources note that Jews living outside Palestine kept on paying their tithes and duties to the Holy Temple (Mendels 1992) ${ }^{4}$ as long as the Temple still stood in Jerusalem (Grïen 2002, 244). However, it is interesting to note that in the wake of the Temple's destruction, the war indemnity, fiscus iudaicus, was levied solely on an ethnic religious basis: namely, Jews who had once paid taxes to the Temple were now forced to contribute, through mandatory taxation, to the war effort, ${ }^{5}$ but such involuntary assessment was

3 See, for example, O.G. Bailey, M. Georgiou, \& R. Harindranath (eds.), Transnational Lives and the Media: Re-imagining Diaspora. London: Palgrave Macmillan 2007.

4 Cicero relates that when economic conditions resulted in a prohibition to export gold, Asia Minor was forbidden from sending gold to the Temple, which provoked disorder not only in that province but also in Rome, and led Flaccus, the Governor, to be sentenced for extortion (Grüen, 244).

5 But it was in reality for the Roman Temple. 
only imposed on those who were somehow associated with the Holy Temple or had been, in some way, part of the revolt. To understand the concept of Jewishness in use at that time (which will be described at greater length below), it must be pointed out that this tax retaliation had no national or racial component; the taxes did make an exemption for Diaspora Jews, as well as those who did not undertake a complete Jewish life, but were instead strictly imposed on the members of the Pharisaic and rabbinic trends, which were most obviously groups involved in the revolt (Mendell 1984). Further, when Domitian (81-96 CE) took power, he reinforced the Jewish poll tax by expanding its classification whereby the burden of such tax would now fall upon a vast number of those who had previously been exempted from having to bear it: namely: part-time or full followers of Jewish practices, apostates, and Diaspora Jews were now all included in the fiscus (Leon 1960; Goodman 1989). During this period, the former definition of what it meant to be Jewish briefly shifted to a much more global, ethnic religious identity, regardless of loyalty to the cause or even to the degree of the person's religious practice.

\section{Who is a Jew?}

Distinctly defined as an "ethno-religious community," Jews were at the same time forming a kind of autonomous polity, with a centre located in Palestine and a periphery dispersed amidst other peoples. One may also recall that there are other objections to the supposed singularity of this Diaspora. First, however, a preliminary distinction must be made regarding the term Jew: that an individual adheres to Judaism, be it through religious observance and/or descent, is a late phenomenon unknown in the ancient period. It is well known that this appellation was coined during the first exile in Babylonia: the earliest occurrence of the term Yehudi is to be found in the Scroll of Esther, where the main male protagonist, Mordecai, is called ha-Yehudi, "the Jew," living in a main city of the Persian empire. The occurrence of this word is not incidental at this time and place. As Josephus explained:

"So the Jews prepared for the work: that is the name [ioudaios] they are called by from the day that they came up from Babylon, which is taken from the tribe of Judah, which came first to these places, and thence both they and the country gained that appellation." (Antiquities of the Jews, 1999 L. XI, 6, 7, 173)

This simple clarification helps to understand that Ioudaios, Ioudaia, Iudeus, Iudea ${ }^{6}$ could have shared a whole range of definitions beyond adherence to the Jewish religion. Moreover, the Judean Roman province was inhabited by all kind of peoples, some having been displaced there by the Romans, some others having lived there since time immemorial. The term "Jew," designating a person belonging to the tribe of Judah or residing in the Kingdom of Judea, which was in the Hebrew Bible the only referents and significations of this term, changed its meaning during the Hellenistic period: it became a geo-

6 During the Hellenistic period, the term Ioudaios, literally "member of the tribe of Judah," became by extension the common name for any inhabitant of the Judean province and thereafter for all those who affirmed either Jewish religion or culture or were simply allies of the Jews in some fashion or another. See Cohen 1999. 
graphical indicator of one's origins. At the same time or later, it also became an ordinary designation for those living in Judea or not, who had some degree of adherence to Jewish practices or who simply sympathized with Jews, politically or religiously. Very puzzling is the relatively late assertion of Dio Cassius $\left(2^{\text {nd }}-3^{\text {rd }} \mathrm{CE}\right)$ saying that Josephus was a "Jew by birth;" he added, "this title [Jew] is also borne by other persons who, although they are of other ethnicity, live by their laws" (Kraemer 1989). Thus, the accepted conception of Jewishness at the time looked much more variegated and expansive than what it is thought of now: being Jewish, either according to our times restricted through birth or conversion, or because one lived or was born in the Judean Roman province, being a proselyte or a pagan only circumcised, were all integrated into the definition of Ioudaios.

Considered as the quintessential singularity of the Jewish people, their particular experience of its exile, or Galut, its persistence without a homeland, is perceived as reflective of its exceptional status in the course of "mainstream" history. When Jerusalem was razed half a century after the destruction of the Second Temple following the suppression of the Great Palestinian Rebellion, the periphery did not disaggregate, but was somehow able to retain a kind of coherent polity for over 2,000 years. Yet, the dispatching the remaining combatants and survivors into slavery, as well as prohibiting the Jews from approaching the crumbling city of Jerusalem, did not, by any means, empty Palestine of its Jews. Forbidden from ever re-settling in Jerusalem, the spiritual and political heart of the Jews was indeed nonetheless kept alive through the autonomy of the Jewish self-government in the Roman province. The development of authoritative Academies in Galilee like Tiberias or Sepphoris, and the central one at Yabne became the refuge shelter of the Pharisaic spirit, which was later illustrated by the production of the Palestinian Talmud, called the "Yerushalmi," to show that the sanctity of Jerusalem extended over the whole of the Land of Israel. The ongoing movement of migration that emptied the land was voluntary, independent of any Roman decision or law.

For one, since the destruction of the Second Temple, the Jewish meaning of Diaspora would gradually change to supplement the mystical Hebrew term Galut, transporting it to a new meaning replete with the theological sense of punishment. Filled with longing and despair, the image of the "Wailing Wall" illustrates and reinforces its evocative power as a space of desolation in the desecrated place of the Holy City. However, this dramatic figure of Jews weeping and lamenting over their incommensurable loss should be counterbalanced by the heritage of the Talmudic view that now, the physical Temple would have to be supplanted by good deeds, prayers and fulfilment of the commandments (Talmud Bavli Berakhot 26b and Sanhedrin 98b). And in a sense the Rabbis' attempt to elevate the sanctity of the Torah over the land of Israel in giving precedence to the sanctification of commandments over Eretz Yisrael (Midrash Rabbah, Gen. 1, 5; Rawidowitz 1998, 208) was a sheer adaptation to a new historical context. Nonetheless, the concept lurking behind this attempt was amplified and circulated by Jewish philosophers during the Middle Ages, and later by Jewish literature since the $19^{\text {th }}$ century: Jews do not need any concrete or territorial centre or a built sanctuary. On the contrary they had a portable spiritual territory and topography: they carried with them, embedded in the expanded Scriptures, ${ }^{7}$ the system of laws required to establish their specific ways of social life. The

7 By this I mean not only the Hebrew Bible and the Talmudic corpus, but also all subsequent interpretations of Jewish literature. 
Jews were the "People of the Book." Accordingly, their real sanctuary is a text, which is in itself a "movable" Temple (Patai 1947; Oppenheimer 1999), incorporating its spirit, prescribing the performing of commandments, rituals, practices and inspiring the daily liturgy.

From this vantage point, it is no surprise to note that thinkers of the Exile were both legislators and mystics: to give only a few examples, Saadia Gaon emphasised the adequacy of "galut" to "present time" (Rosenblatt 1976, chap 8), Maimonides saw exile as "coercion" and put its responsibility to "our ancestors" (Epistle to Yemen, Halkin 1993); Nahmanides, understood exile as a crisis of the Divine and elevated it to the most mystical and religious degree: "Exile is meted out for the delay of Justice, the perversion of justice [...] and for the nonobservance of the shemittah, the Sabbath of the land, for her repudiator repudiates Creation and the Future World" (on Lev; Henoch 1997, 382). In that sense, and in contrast to other nations, Jews do not require a homeland in order to persist as a nationally and religiously organized people. In addition, since the Enlightenment and the integration of the Jews into the nations, a new approach grounded on the idea of the mission of the Jewish Diaspora was developed.

According to this conception, two opposite visions of the interdependence of the Jews to their land have competed with one another in the innermost core of Jewish discourse since long before the Common Era: the power of Diaspora to repair the sin of the ancestors with the fulfilment of the Torah or maintaining the sacred inherent to Eretz Yisrael. Both signal one of the most lasting conflicts at stake during the entire history of the Jews: the messianic struggle for hastening the Redemption which would bring the exile to its end, while expediting the return of the "remnants of Israel" back to their original homeland (Silver 1927).

\section{Survival of the Jewish Nation by Departing into Diaspora: Jeremiah's Argument}

No other example can better illustrate this conflict at work in Judaism between the pre-eminence accorded to living in Palestine to maintain residence in the Promised Land versus the readiness to abandon it than in three chapters of the Book of Jeremiah.

Mandated by God to warn the Jews about their imminent deportation to Babylon and the threat of destruction of the City and the Temple, Jeremiah caused such great hostility amidst the Jews that when he announced his prediction, not only was he almost murdered by his Jewish brethren, but his prophecies engendered further predictions from other socalled "prophets" (Jer. 28), proclaiming that the reign of Nebuchadnezzar would not last very long and that all the sacred belongings and vessels of the Temple would be returned to the Holy Land after a very short time.

Especially interesting for our purpose are the sayings of Jeremiah and the admonition he delivered to the people. At first, when the discussion was opened with Hananiah, the rival pretender to prophecy, Jeremiah could not convince the people of his own predictions, for they preferred his rival's optimistic visions. Reluctant as they were to accept to leave voluntarily, the Jews had no alternative but to face the reality of defeat. Fighting to their death would be hopeless, and the King of Babylon's victory was inevitably God's decision. His punishment of the Jews was mandated for not having paid attention earlier to the warnings Jeremiah had given to them. Once the divine decision was made, Jeremiah sent his famous letter to the prisoners in Babylonia. Even if its content is well known, it is useful to quote one passage: 
"This is what the Lord Almighty, the God of Israel, says to all those I carried into exile from Jerusalem to Babylon: 'Build houses and settle down; plant gardens and eat what they produce. Marry and have sons and daughters; find wives for your sons and give your daughters in marriage, so that they too may have sons and daughters. Increase in number there; do not decrease. Also, seek the peace and prosperity of the city to which I have carried you into exile. Pray to the Lord for it, because if it prospers, you too will prosper.' Yes, this is what the Lord Almighty, the God of Israel, says: 'Do not let the prophets and diviners among you deceive you. Do not listen to the dreams you encourage them to have."” (Jer. 29, 4-8)

The message Jeremiah has transmitted is lucid, without any ambiguity: even though a king has vanquished you, you have to be aware of the fact that it is Divine retribution, which falls upon you. You have to remember that He is the God of History, and as His chosen people, nothing would happen to the Jews unless it is His decision. Holding kings and emperors in His hand, $\mathrm{He}$ uses them as instruments. Thus, fighting to the death against the kings would be a mockery of God's will and it is better to admit your fate and surrender than to dare defy God's will. However, this surrender - which means submission to God's will - was to ensure the Jews survival as a nation. This meant to dwell far from Eretz Israel, to build new homes for the families they would produce. As heads of households, the displaced in Babylon should cultivate gardens, plant fruits and vegetables to feed them, and grow vineyards to perform the Divine commandments. They should find wives, spouses for their daughters and sons, in order to bear new children and preserve His people. Compellingly, the last verse is illuminating for our purpose: be faithful to the kingdoms wherever you settle and seek peace and prosperity there. For the future of Jewish history, the words Jeremiah sent to the captives were taken to be a firm commitment.

\section{The Making of Judaism Between Common and Jewish Law: A Creation of Diaspora}

Since this very first experience of collective displacement, ${ }^{8}$ the phenomenon of dispersion became one of the driving forces behind later evolutions of Judaism. The books of Ezra and Nehemiah make us aware of certain facts: the elite displaced to Babylonia forged particular ways of conduct to maintain for themselves a strong sense of their Jewish identity. When they were permitted to return to their land, some generations later, they brought new rules back to Israel. ${ }^{9}$ This updated Judaism, with the laws at its core (Neh. 10 ), pervaded the ordinary ways of Jewish observance.

However, two crucial events happened during the 70 years of sojourn in Babylon. First, in the absence of the Temple and thus unable to perform sacrifices, ${ }^{10}$ the Jews had to conceive of new ways to be Jewish. Second, when Jews were able to finally come back

8 There is no record about the fate of the "lost" tribes, which existed long before.

9 Circumcision, strict observance of the Sabbath, endogamy, synagogues, name of the months and lunarsolar calendar are the most notorious.

10 Nonetheless, there is evidence of the existence of, at least, two other Jewish temples in the course of the history. The first one was the temple of Elephantine, during the reign of Darius (444 BCE) and the second was the Egyptian temple of Onias which stood for two centuries in Leontopolis (166 BCE-73 CE). 
to Palestine to reconstruct the land and build the Temple anew under the command of Ezra and Nehemiah the Scribe, the majority of them stayed in Babylonia (Neusner 1997, 222), where they purposefully chose to perpetuate their form of Judaism. While both the books of Jeremiah and Ezekiel bear witness to the newly theological importance accorded to the meaning of the term "exile", the books of Ezra and Nehemiah especially attest to the emergence of the messianic impulse given by Zerubavel and Joshua with the rebuilding of the Temple and the proclamation of the Law. This theological movement which constantly grew in intensity since the Maccabean revolt, continued during the Hasmonean period, until the first century, and culminated in the last war led by Bar Kokhba (132-135 CE).

However, it is striking to contrast this with the Scroll of Esther, written at some imprecise time during the Persian period, ${ }^{11}$ for it shows neither any form of yearning for the Land nor any messianic impulse. It does not even envision the idea of taking advantage of the favourable situation in which the Jews found themselves vis-à-vis the Persian rulers to bring back the Jews from Persia to Palestine. On the contrary, the text seems to draw attention to the importance of Jewish life in "diaspora." However, the Pseudepigraphical literature, written in Palestine between the third and the first centuries BC, describes, through the voice of the Psalmist, the classical theological picture of the Jewish destiny: "among every nation are the dispersed of Israel accorded to the word of God" (Ps. 9, 2). Other verses from the Third Sibyl share the same ethos: "And even thou, forsaking thy fair shrine, shalt flee away when it becomes thy lot. To leave the holy ground, and thou shalt be carried to the Assyrians, and shalt see wives and young children serving hostile men. All means of life and wealth shall be destroyed, and every land and sea be filled with thee ..." (Syb Or. 3, 315-320). Curiously enough, this is historically echoed by Strabo, the Greek geographer, who lived at the time of Augustus: "There were four classes of men among those of Cyrene; that of citizens, that of husbandmen, the third of strangers, and the fourth of Jews. Now these Jews are already gotten into all cities; and it is hard to find a place in the habitable earth that hath not admitted this tribe of men, and is not possessed by them ..." (Antiquities oft the Jews XIV, 7).

All the same, even when the diverse meanings of the term Ioudaios in the Greek Roman world are taken into account, Jews were in considerable proportions, sometimes even in greater numbers, more outside than inside their homeland (Safrai 1974). Thus, as is already known, the huge Alexandrian, Roman and Antioch Jewish communities represented the most legendary instances of remote Jewish centres, inasmuch from the perspective of demography, than from the perspective of cultural life, power, and influence.

Philo of Alexandria ( $1^{\text {st }}$ cent.) explains this situation in his own terms:

"For no single country can contain the Jews because of their multitude, and for this reason they inhabit the most extensive and wealthiest districts in Europe and Asia both on islands and on mainlands, and while they regard the Holy City as their mother-city, in which is founded and consecrated the temple of the most high God, yet they severally hold that land as their father-land." (Pearce 2004)

11 For a recent tentative date of Esther's Scroll, see Friedberg 2000.

12 63/64 BCE - ca. 24 CE. 
Does this mean that Philo made a sharp distinction between the ancestor's land and the place where Jews actually lived? Is he expressing the centrality of the city in the sense of loss, or even the opposite, as that as of a place of exile? Sarah Pearce observed that, excepting biblical mentions from the Greek text, Philo never used the term "diaspora" to be associated with a means of punishment mentioned above, and used instead Apoikiai, meaning, bluntly, "colony." According to her, it is more likely that he was not differentiating between a "mother-city" (metropolis) and a "father-city" (petropolis): both would be cities, the first one being a city with a temple, just as other "mother-cities" of the Hellenistic world. Moreover, from the testimonies of both Josephus and Philo, it appears that Jews were not only a constitutive part of the Hellenistic world, but were dispatched to all its parts, benefiting every place they inhabited, as Philo explained. However, when he had to clarify the relationship of the Jews to Jerusalem he states:

"Concerning the holy city $[\ldots]$ is my native country, and the metropolis, not only of the one country of Judaea, but also of many, by reason of the colonies which it has sent out from time to time into the bordering districts of Egypt, Phoenicia, Syria in general, and especially that part of it which is called Coelo-Syria, and also with those more distant regions of Pamphylia, Cilicia, the greater part of Asia Minor as far as Bithynia, and the furthermost corners of Pontus. And in the same manner into Europe, into Thessaly, and Boeotia, and Macedonia, and Aetolia, and Attica, and Argos, and Corinth and all the most fertile and wealthiest districts of Peloponnesus." (Legatio, 281-282)

As it may be understood, the Jews, dispatched all over the territories of the Hellenistic world, were integral actors in the social fabric of their respective locality. They were involved in both economic and political spheres, and often enjoyed many civic rights in the cities where they had come to settle. Philo, evoking his city, said "our Alexandria" (Grüen 2002, 242). In addition, one who tried to seek any expression of longing or being torn away from their homeland in his writings would hardly be able to find it.

\section{The Essence of Galut: The Inner Contradictions of Being Under Foreign Laws}

"How much did Jews in the Diaspora care about the catastrophic defeat of their brothers in Judea in A.D. 70? [...] Jews in the cities around Palestine, as also in Antioch and in Alexandria by Egypt were dragged into the conflict by the attacks of their gentile neighbours, but they singularly failed to flood to the rescue of Jerusalem [...]." It is by asking this harsh question that Martin Goodman opens his article recounting the reactions of the members of the Diaspora with respect to the destruction of the Temple (Goodman 1989). His smoothly nuanced answer opts for overconfidence rather than indifference. Probably he is right! However, perhaps the answer should be even more balanced as far as the widespread conceptions at this time are concerned. Furthermore, the absence of a unified Jewish politics makes it impossible to discern exactly the extent of support the uprising against the Romans had raised among the Jews dispersed throughout the Empire, which stretched from Rome to the far reaches of Europe and around the entire Mediterranean 
Basin. The absence of any reported turbulence in the ancient sources might reinforce this (Goodman 1989, 30).

In regard to the extreme diversity of Jewish cultural or religious trends, ${ }^{13}$ beliefs and practices at this time, and considering in addition, the unavailability of Jewish norms until the emergence of the rabbinical literature, it is hardly possible to gain an appreciation of the ways in which the word "galut" was understood. Our current system of references, inherited from centuries-long interpretations about the meanings and computations of its foreseeable end, deeply obscures our understanding of how it could have been perceived exactly at this time.

Judaism commemorates the destruction of the two Temples on the same day, the 9th of Av. By doing this, both events are integrated and understood as one and the same disaster, which links Jewish history to the harsh exile prophesied in the Bible. According to Chaim Milikovsky, it was not so easy for the rabbis to impose the $9^{\text {th }}$ of Av as the exact date of the burning of the First Temple (Milikowsky 1993). Skipping over this insolvable problem of establishing a precise date for the events described in the Bible, one might point out that Josephus, already in his time, stated that both disasters occurred on the same day. ${ }^{14}$ It means that an oral tradition relating to the destruction of the First Temple was already circulating quite some time before the redaction of the Talmud (Talmud Bavli Ta'anit 3,9). Furthermore, in yet another article, Milikowsky (1997) has shown that the trilogy - conquest, destruction of the Temple, exile - which serves as the basic motif for Jewish traditional construal of disaster, was indeed actualized to integrate the tragic events of the first century in the same scheme as the Babylonian one. Only later, in the following centuries, did the rabbis introduce the notion that both situations, the conquest by the Babylonians and the conquest by the Romans, were to be understood in light of the same prophesies and would also have the same ending: the return of the exiled and the reconstruction of the Temple. It certainly does not mean that close contemporaries made light of the tragedy. On the contrary, one should consider the fact that a new era was established then (Goldberg 2000), and the Jews perceived it as an unknown or unpredictable event in their history. Moreover, as follows from Milikowsky's analysis (1997), this scheme fused into Jewish motifs only centuries later, and the historical sources that attest to the inclusion of both events into the same notion of Galut did not materialize until the situation had lasted for so long - or even worsened - and the feeling arose that it could endure endlessly.

So what was at stake in these sources? Milikowsky has shown that "galut" was understood partly as subordination to a foreign power and partly as eradication of an entire people from their land. But Roman Palestine, Eretz Yisrael, was still inhabited by Jews, and in the absence of the Temple, the sanctity of Jerusalem was extended to the whole country through the presence of the Sages and their vibrant activity in the academies. Moreover, pilgrimages and visits to Jerusalem were maintained after the fall of the Temple (Safrai 1974, 211). ${ }^{15}$ Therefore, the phenomenon of this dispersion, which was more or less voluntary and partial, was nothing compared to the absolute state of emptiness accorded to the land during the Babylonian Exile. So, this dispersion was no reason to

13 For whom there is only the testimony of Josephus and the mention made by Philo.

14 It was actually burnt on the 10th if we rely on Josephus, The Jewish War, VI, 5.

15 See Cant Rabba 4. 
account for the perception of the notion of exile the closest contemporaries had! ${ }^{16}$ By contrast, when the rabbis of the Talmud, some four to six centuries later, tied the Babylonian and the Roman exiles together to locate their present position in the course of history, these difficulties were already solved: Jews had massively fled Palestine in quest of more welcoming places. Eventually, they indeed were all submitted to the rules of foreign powers, be they Christian-Byzantine or Persian.

\section{The Exile as an Everlasting Fate: The Legal Response to Diaspora}

In biblical times, Jeremiah posited the argument of exile as a condition of survival: to persevere as a people, Jews would have to dwell in peace and multiply in whichever place they resided. At the time the Talmud was compiled, two separated branches of Judaism, so to speak, were located in two different empires. ${ }^{17}$ While the Palestinian Talmud had been concluded in the $4^{\text {th }}$ or $5^{\text {th }}$ centuries in a particular territorial space under the domination of the newly born Christian empire, the Babylonian Talmud was completed much later, in the $6^{\text {th }}$ century under Persian rule. Whether incidental or not, it is in the Babylonian corpus that the political principle which had governed Jewish life since that time is to be found: the "Law of the Kingdom is Law," dina de-malkhuta dina (Shilo 1974).

The paternity of this Talmudic formula is attributed to the Amora Mar Samuel, who lived in the $3^{\text {rd }}$ century. Its main use was to ensure that the rabbinical decisions complied with the common law of the state, whenever such a decision questioned or contradicted particular points of the Halakha, such as regarding taxes or decrees. It was intended to allow in each pending case to suspend any decision and to apply the rule of dina demalkhuta dina (Walzer, Lauberbaum \& Zohar 2000).

Proud to be the supposed direct heirs of the First Exile, the Babylonian Jews might have obeyed the admonition of the prophet better than their brethren in Palestine. Hence, it is no surprise to notice that while the Palestinians would not stop rebelling and fighting against the foreign powers subjugating them, Babylonians would seek peacefully to abide by external power rules. More importantly, the Babylonians seem to have founded the notion of exile on a mystical principle and conceived Diaspora as a standard for Jewish life, enacted by God to perpetuate his people as long as He would not reverse His decision.

It is striking that while this principle is cited six times in the Babylonian corpus, there is not even a single mention of it in the Palestinian one. Without real legal contents at its inception, the formula, which might only have been a simple motto, would eventually constitute a part of the full theory of politics produced by rabbis who turned themselves into law theorists (Landman 1968). We find in the literature of the responsa the same legal developments, which are, in essence, part of general laws of normally constituted

16 "Early rabbinic literature [...] did not perceive the events surrounding the Roman conquest of Jerusalem at the time of the destruction of the Second Temple as including a mass exile of the Jewish people [...]. Only as the period of the Temple's nonexistence lengthened, and as the population of the Jews who lived in the Land of Israel became less and less, were these two unrelated phenomena conceived as both deriving from the Roman conquest of Jerusalem in 70 CE.” (Milikowsky 1997, 280)

17 It is generally admitted that the Talmudic compilation, assembling the oral law, began in parallel under Roman and Neo-Persian rule in the first part of the 3rd century. 
states imposed in their land: relations to divine right, to popular assent, to admitted custom, to feudal laws, etc. More generally speaking, the corpus of the Law of the Kingdom's rules specially addresses the realm of legal conduct concerning the relations between Jews, on the one hand, and between Jews and Gentiles on the other.

Ironically enough, it turned out to be the burden of those who claimed to be the direct heirs of the Palestinian legacy (Yuval 2006; Goldberg 2008) to work out these legal theories. Between the $11^{\text {th }}$ and the $13^{\text {th }}$ centuries, the Ashkenazic rabbis of medieval Europe elaborated the main lines of the inner structure of the Jewish administration of the community, the Kahal (Schwarzfuchs 1986; Grossman 2004), and at the same time they defined the relations to an external State. Furthermore, one may notice that in Ashkenaz, the Jewish community's leadership was divided into secular and spiritual bodies, according to a divide founded on the recognition of the individual's capacity and knowledge, and was then submitted to legal rabbinic ordination - as was the case in Palestine (Agus 1969). In contrast with Spain, not only did the State appoint the leaders of the Aljama, Jewish community, but to perform as religious leaders, rabbis did not need to obtain the position through rabbinic ordination, as was the case in Babylonia (Goldberg 2004). Thus, in some ways, whereas the Sephardic Diaspora prolonged the legal and integrative conception of the Babylonian Galut - almost entirely submitted to the will and decision of the external state, the Ashkenazic Diaspora perpetuated the Palestinian attitude to the Roman occupation. Galut was understood as coercion and perceived as a continuum of violence against its self-government. Indeed Ashkenaz maintained its judicial frame of internal autonomy inherited from the Palestinian pattern until the abolishment of the Community in the wake of emancipation, during a process which started with the French Revolution and lasted down to the Russian Revolution.

\section{The here and now}

To conclude this precarious attempt to draw a thread between past and present, current and well-known approaches, by trying to revive a former largely unknown world which has left scarce traces, the question remains open: is it really possible now to portray somehow a picture of what might have been a common law opposed to a Jewish law? Examples of such cases are numerous throughout the long history of the Jews, as is the case with familial or personal status, marriage and divorce, inheritance, judgment, oath, commercial practice and extending all the way to taxes. The most illustrious case was Napoleon's call for a new "Sanhedrin" in 1806, which was supposed to impose on the rabbis the lofty goal of demonstrating that Jewish Law was compatible and adjustable to the whole framework of the legal status of individuals and legal general laws of the State. It was the first attempt to find a way to solve the absolutely puzzling problem of the division between religious and civil laws intrinsic to the nuclear conception of Judaism, conceiving it as an everlasting frame to be applied in any foreign state where Jews might live, forming as it was often said "a state in a state."

Leaving aside for a moment the fact that "diaspora" is a word used to refer to a situation shared by many other peoples, I have tried to recall that the Jewish theological notion of Galut has little to do with geographical dispersion, and to describe how rabbinical Judaism discovered in this notion the expression of the unique fate of the Jewish People, bound to live according to the laws enforced in its alien (Christian) environment (Yuval 2006). I have suggested that, on that basis, a Jewish way of life derived from a single principle keli golah asse lekha - literally "Do for yourself a tool (keli) for exile" (Jer. 46, 
19). ${ }^{18}$ And I still contend that this is what gives its specificity to the meaning of Diaspora in Judaism. To put it differently, and leaving the last word to the great Isaiah Horowitz (SHeLaH), I would like to recall a passage from his magnificent opus, Shenei luhot haberit - The Two Tables of the Covenant - (Horowitz 1649, fol 349), where he describes his astonishment at his contemporary Jews: "When I saw in this world the children of Israel building for their own use houses like princely palaces, building permanent houses made of stones in a land of impurity [...] it was as if they had renounced redemption."

\section{Bibliography}

Agus, A. (1969) The Heroic Age of Franco-German Jewry. New York: Yeshiva University Press.

Ben Raphael, E. (2002) Jewish Identities: Fifty Intellectuals Answer Ben-Gurion. Leiden: Brill.

Cohen, S.J.D. (1999) The Beginnings of Jewishness. Boundaries, Varieties, Uncertainties. Berkeley: University of California Press.

Diodorus Siculus (1989) Library of History. Diodorus of Sicily in twelve volumes with an English translation by C. H. Oldfather, Cambridge, MA: Harvard University Press; London: William Heinemann, Ltd. http://www.perseus.tufts.edu.

Dromi, U. (ed.) (2005) Shevet Ahim. Yehasei hilonim-datiyim: emdot, hatsaot, emunot. Jerusalem: Makhon ha-israeli le-demokratiah.

Elazar, D. (1983-1997) Kinship and Consent. The Jewish Political Tradition and its Contemporary Uses. New Brunswick, London: Transaction.

Friedberg, A.D. (2000) A New Clue in the Dating of the Composition of the Book of Esther. In: Vetus Testamentum 50(4): 561-565.

Goldberg, S.A. (2000) La Clepsydre. Esssai sur la pluralité des temps dans le judaïsme. Paris: Albin Michel.

Goldberg, S.A. (2004) Dina de-malkhuta dina La loi du Royaume est la loi. In: AlvarezPereire, F.; Pananfit, L. (eds.), Le droit interne hébraïque. Strasbourg: Presses Universitaires de Strasbourg, 103-117.

Goldberg, S.A. (2008) La tradition comme notion et comme principe. In: VartejanouJoubert, M., Herméneutique et bricolage. Bern: Peter Lang, 97-112.

Goodman M. (1989) Diaspora Reactions to the Destruction of the Temple. In: Dunn, J.D.G. (ed.), Jews and Christians: The Parting of the Ways, A.D. 70 to 135. The second Durham-Tübingen Research Symposium on Earliest Christianity and Judaism, Durham, September 1989, Michigan-Cambridge, U.K: Grand Rapids (2 $2^{\text {nd }}$ edition (1992), Tübingen: Mohr), 27-38.

Grossman, A. (2004) The Jewish Community in Ashkenaz in the $10^{\text {th }}-11^{\text {th }}$ Centuries. In: Grossman, A.; Kaplan, J. (eds.), Kelal yisrael. Jewish Self Rule Through the Ages.

18 There is no English translation to render exactly the Hebrew meaning of this verse. See for example. The King James version has: "furnish thyself to go into captivity" and New King James International: "Prepare yourself to go into captivity!;" the New Standard American Bible has the more modern phraseology: "Make your baggage ready for exile." The closest would be the JPS: "Equip yourself for exile," see http://biblebrowser.com/jeremiah/46-19.htm. 
Vol. 2: The Middles Ages and Early Modern Period (hebr.). Jerusalem: Zalman Shazar Center, 57-74.

Grüen, E. S. (2002) Diaspora Jews amidst Greeks and Romans. Cambridge: Harvard University Press.

Gutman, R. (2000) Le document fondateur du judaïsme français: les décisions doctrinales du Grand Sanhédrin 1806-1807. Strasbourg: Presses Universitaires de Strasbourg.

Halkin, A. (1985, 1993) Epistles of Maimonides: Crisis and Leadership. Philadelphia: Jewish Publication Society.

Henoch, C.J. (1997) Ramban. Philosopher and Kabbalist, On the basis of his Exegesis to the Mitzvoth. Northvale, New Jersey, Jerusalem: Jason Aronson.

Herodotus The Histories (ed. A. D. Godley). http://www.perseus.tufts.edu.

Horowitz, I. (1649) Shenei Luhot ha-berit. Amsterdam.

Sibylline Oracles. http://www.elfinspell.com/SibyllineOracles.

Josephus Flavius (1999) The Antiquities of the Jews. Trans. by William Whiston, The New Complete Works of Josephus, Grand Rapids: Kregel.

Kraemer, R.S. (1989) On the Meaning of the Term 'Jew' in Graeco-Roman Inscriptions. In: History of Theology and Religion 82: 35-53.

Landman, L. (1968) Jewish Law in the Diaspora: Confrontation and Accommodations. Philadelphia: Dropsie College.

Leon, H.J. (1960) The Jews of Ancient Rome. Rev. edition (1995). Peapody Mass.: Endrickson Publishers.

Mendell, A. (1984) Who Paid the Temple Tax When the Jews were Under Roman Rule? In: History of Theology and Religion 77(2): 223-232.

Mendels, S. (1992) The Rise and Fall of Jewish Nationalism. Jewish and Christian Ethnicity in Ancient Palestine. Michigan - Cambridge UK: Grand Rapids.

Milikowsky, C. (1993) The Date of Destruction of the First Temple According to Seder Olam, the Tosefta and the Babylonian Talmud (hebr.). In: Tarbiz 62(4): 485-500.

Milikowsky, C. (1997) Notions of Exile, Subjugation and Return in Rabbinic Literature. In: Scott, J. M. (ed.), Exile Old Testament, Jewish and Christians Conceptions (SJSJ 56). Leiden: Brill, 265-295.

Neusner J. (1997) Exile and Return as the History of Judaism. In: Scott, J.M. (ed.), Exile Old Testament, Jewish and Christians Conceptions. Leiden: Brill, 221-248.

Oppeheimer A. (1999) Judaism from Temple to Text. In: idem (ed.), Sino-Judaica. Tel Aviv: Tel Aviv University, 81-92.

Patai, R. (1947) Man and Temple in Ancient Jewish Myths and Rituals. London: Nelson.

Pearce, S. (2004) Jerusalem as "Mother-City" in the Writings of Philo of Alexandria. In: Barclay, John M.G. (ed.), Negotiating Diaspora: Jewish Strategies in the Roman Empire. London: T \& T Clark (Library of Second Temple Studies 45), 19-37.

Philo of Alexandria. http://www.earlyjewishwritings.com.

Psalms of Solomon. http://www.earlyjewishwritings.com.

Rawidowitz S. (1986/1998) State of Israel, Diaspora and Jewish Continuity. Essays in the "Ever-Dying People," Hannover: University of New England.

Safrai, S (1974) "Relations Between the Diaspora and the Land of Israel" and "Jewish Self-Government." In: Safrai, S. and Stern, M. (eds.), The Jewish People in the First Century. Historical Geography, Political History, Social, Cultural and Religious Life and Institutions. Vol. 1., Assen: Van Gorcum \& Comp, 184-215; 377-419.

Schechter R. (2003) Obstinate Hebrews. Representations of Jews in France 1715-1815. Berkeley, Los Angeles, London: California University Press. 
Schwarzfuchs S. (1986) Kahal. La communauté juive de l'Europe medievale. Paris: Maisonneuve \& Larose.

Schwarzfuchs S. (1979) Napoleon, the Jews, and the Sanhedrin. London: The Littman Library of Jewish Civilization, Routledge \& Paul Kegan.

Shilo, Sh. (1974) Dina de-malkhuta dina. The Law of the State is the Law (hebr). Jerusalem: Academic Press.

Shmueli, E. (1980; 1990), Seven Jewish Cultures. A Reinterpretation of Jewish History and Thought. New York, Cambridge: Cambridge University Press.

Sibylline Oracles (1890) Translated from the Greek into English by Milton S. Terry, New York: Hunt \& Eaton; Cincinnati: Cranston \& Stowe's, 315-320.

Silver, A.H. (1927) A History of Messianic Speculation in Israel. From First to the Seventh Century. New York: Macmillan.

Van Unnik, W.C. (1993) Das Selbstverständnis der Jüdischen Diaspora in der hellenistisch-römischen Zeit (AGJU 17). Leiden: Brill.

Walzer, M.; Lorberbaum, M.; Zohar, N.; Loberbaum, Y. (2000) The Jewish Political Tradition. Vol. 1: Authority, New Haven, London: Yale University Press.

Yuval, I. (2006) The Myth of the Jewish Exile from the Land of Israel. A Demonstration of Irenic Scholarship. In: Common Knowledge 12(1): 16-34.

Sylvie Anne Goldberg is currently a professor of History of the Jewish People at the Ecole des Hautes Etudes en Sciences Sociales (Ehess, Paris). She is particularly interested in aspects of cultural and religious evolutions. Publications: Illness and Death in Ashkenazi Judaism in Sixteenth-through Nineteenth-Century Prague. Berkeley/Los Angeles: University of California Press, 1996; La Clepsydre II, Essai sur la pluralité des temps dans le judaïsme. Paris: Albin Michel, 2000; La Clepsydre II, Temps de Jérusalem, temps de Babylone. Paris: Albin Michel, 2004 (both forthcoming also at Göttingen: Vandenhoeck \& Ruprech).

E-mail: sag@ehess.fr.com 